Anait Daniielian, $\mathrm{PhD}$

Natalia Bolharova, $\mathrm{PhD}$

\title{
METHODOLOGICAL ASPECTS OF PROJECTING ENVIRONMENTAL ENERGY EFFICIENT BUILDINGS
}

Kyiv National University of Construction and Architecture, Ukraine

Summary. The article is dedicated to methodology of eco-design and technical aspects of energy efficient buildings projecting. The concepts of the life cycle of the eco-object and life cycle ecologization are considered. The scheme of life cycle epy eco-object is presented and described.

The basic principles of construction of geometrically interpreted physicomathematical models of processes of heat exchange of energy efficient buildings are revealed. It is noted that the use of building decomposition methods, which is appropriate for dividing the object into simpler elements, allows to present the building in the form of three main energy interconnected subsystems: the energy influence of the external climate on the building envelope; energy contained in the shell of the building, i.e. in the outer enclosure of the building; energy contained inside the building, i.e. in indoor air, indoor equipment, indoor enclosure structures and the like. If necessary, each of these subsystems can be represented by the method of decomposition into smaller, energy-related elements. The design of an energy efficient building is to optimize the three energy interconnected subsystems and the building as a whole as a single energy system.

Also, the article describes three stages, which includes the design of energy efficient building in accordance with the principles of system analysis: 
construction of a mathematical model of heat and mass transfer processes in the building; choice of target function; solution of the set optimization problem.

Therefore, as one of the most urgent tasks in determining the level of energy efficiency of buildings and structures is the analysis of their thermal balance, taking into account all energy and energy losses, so the further development and creation of new models of thermal balance of premises is an important and urgent task.

Keywords. Eco-design; ecologization in design; the life cycle of an object; energy efficiency; thermal balance.

Problem statement. Environmental problems of the present have given generations of architects and engineers who combine eco-architecture, design and construction through green building, introduced green certification system compliance systems (such as LEED, BREEAM, and Green Globe, etc.) all over the world. When talking about eco-design, it's about designing energy-efficient buildings, while none of the certification systems of the eco-class objects consider the principles of object creation, the complexity and systematic use of them.

The main part. Commonly, an energy efficient building is represented as a system of independent, innovative energy-saving solutions. At the same time, it is not indicated that these independent decisions can reduce their overall efficiency, and in some cases even lead to negative environmental effects. Forming, geometric modeling, development of concepts of a systematic approach to the design of energy-efficient eco-objects are not considered at all.

The method of system analysis should become the basis of the design methodology of this type of buildings. The ecology of the object should be ensured at all stages of the life cycle from conceptual design to the end of the service life. 
The life cycle of an object is a multi-stage process of its design, creation, operation, completion of operation (it can be utilization or renovation). To determine the environmental sustainability of the object in time, we introduce the concept of ecologization of the life cycle of the object. Ecologization of the life cycle of the object - the compliance of the object with the environmental conditions at all stages of its life cycle. Ecology must be ensured at each stage of the life cycle of the object in such a way that the set of decisions taken has a positive environmental effect. Fig. 1

The life cycle of an object of construction consists of six stages: definition of the concept, designing (object, constructive, technological, engineering solutions), production of materials (natural or synthetic origin), construction, operation (functioning, exploitation), expiration of operation (deconstruction or building renovation and extension of service life). Fig. 1

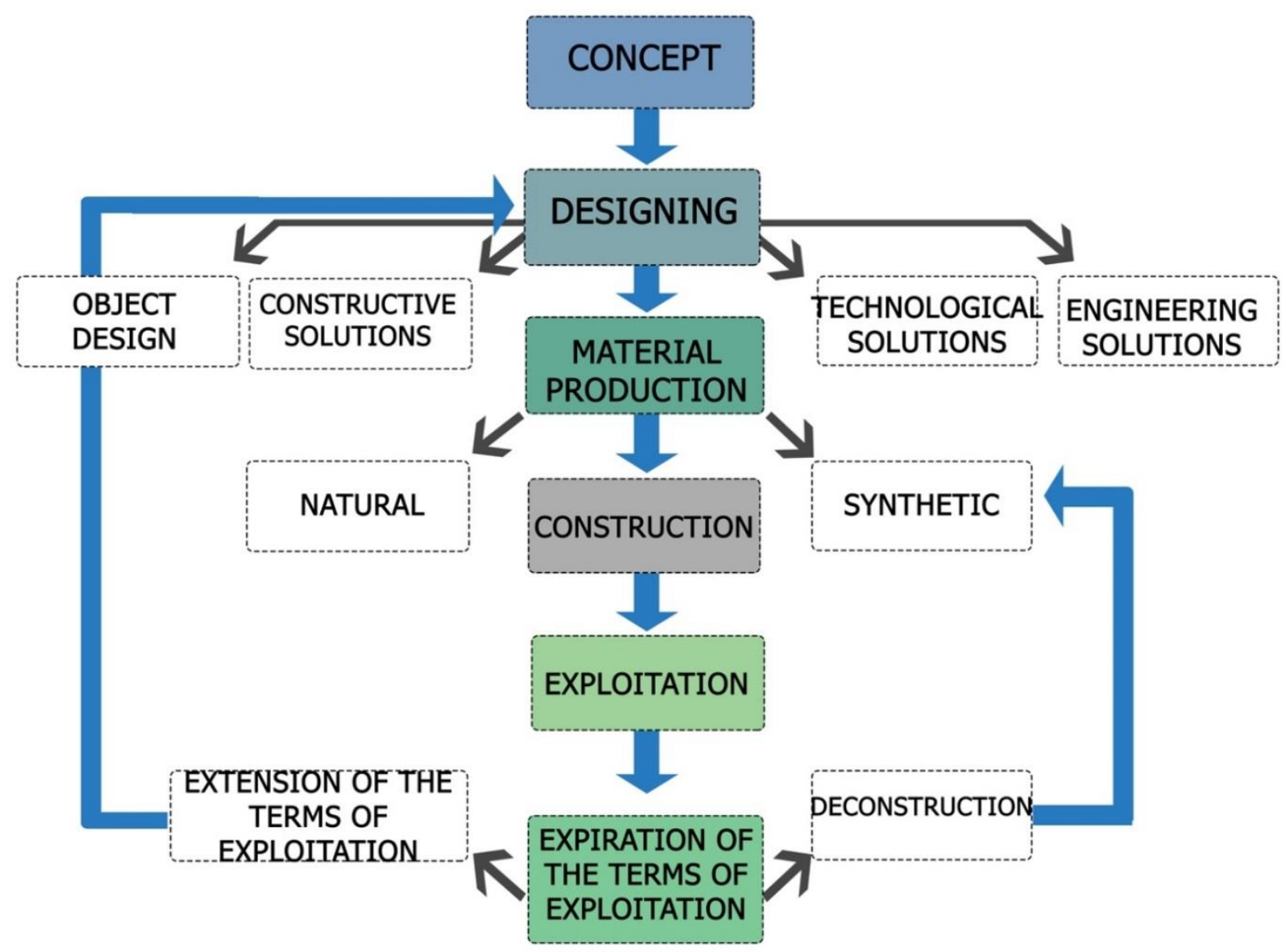

Fig. 1. Ecologization of the life cycle of the object 
Each stage in the life cycle has its own characteristics of environmental friendliness. One of the requirements for modern construction projects is extending the period of their operation, therefore it is obvious that the fifth stage of the life cycle of the eco-object - functioning - occupies the largest share of the total life cycle. Consider the signs of environmental performance of the ecoobject:

1. The durability of the object.

2. Economic feasibility of construction and operation.

3. The level of emissions and environmental impacts during the operation of the eco-design object should be significantly reduced, minimized.

4. Application of recirculation systems: electricity, water, air, biological waste. Such measures help to significantly reduce the consumption of urban resources, the use and exhaustion of non-renewable natural resources.

5. Determination of the level of wear of urban engineering networks. This factor needs to be taken into account when assessing the environmental friendliness of each new object, because in order to increase the economic benefit of creating a specific object, it is connected to existing urban engineering networks without taking into account the factor of their wear and need for renovation in the long run.

6. Determination of the level of exhaustion of natural resources. Loading and depletion of soils, groundwater exhaustion, drinking water consumption, the use of natural materials, destruction of natural flora - all these consequences of the operation of the object must be taken into account when assessing its environmental performance.

7. In the eco-design process, it is necessary to apply mechanisms for reducing the use of non-renewable natural resources. (Alternative sources of electricity, recirculation, collection and treatment systems, recirculation and air purification systems, etc.). 
8. Determination of the level of use of renewable natural resources of the environment. The higher the use of alternative sources of energy, systems for the use of rainwater, the less the negative impact of the object on the environment.

9. Application of measures on ecologization of the environment. Such measures include: the use of air purification systems, purification of reservoirs, the use of measures to improve soil condition, restoration of groundwater level, greenery of the environment, restoration of local flora and fauna, etc.

10. The energy balance of an object in the process of exploitation is the difference between consumption and generation of electricity. The energy balance of an object can be positive (positive), negative, or zero.

Negative energy balance - the ratio between consumption and energy when the amount of electricity produced is less than the amount consumed. Such buildings partially cover their electricity needs, while the rest are from central city electricity networks.

Positive (positive) energy balance - the ratio between consumption and generated energy, when the amount of electricity generated is greater than the amount consumed. Such buildings not only cover their electricity needs but also supply excess to urban networks or other facilities.

Zero energy balance - the ratio between consumption and energy when the amount of electricity produced is equal to the amount consumed. Such buildings completely cover their electricity needs, do not require additional power from city networks, but do not generate excess electricity for the needs of the city.

In the design process, the authors decide on the feasibility of using one or another building and finishing material, technological and constructive solutions, based on a number of criteria that are specific to eco-design. It is sometimes impossible to meet all the requirements, as some of them contradict each other. Therefore, the task of the authors of the project as a result of the 
analysis and application of the system approach, to choose the optimal, most appropriate decisions for all components of the project to ensure maximum efficiency of the object in operation.

The mathematical model of a building as a single energy system can consist of the following three sub-models: mathematical model of the external climate; mathematical model of heat transfer through the building envelope; mathematical model of radiant and convective heat transfer in building premises.

The system of elements and connections simulating the thermal regime of the room can be represented as a graph, in which each element of the room, as a single heat energy system corresponds to the top of the graph, and the connections between the elements of the room or to the external elements are an arc of the graph. In this case, the vertices of the graph can be connected not by one, but by two equally directed arcs, which reflects the transfer of energy through different types of heat exchange.

In accordance with the nature of the studied process of forming the thermal regime of the room and building, we will distinguish probabilistic and deterministic mathematical models that describe this process. Probabilistic mathematical models usually describe stochastic processes that reflect the laws of the distribution of discrete and continuous variables, as well as the distribution of statistics (samples). Deterministic models usually describe the process without the use of statistical probability distributions. But it does not necessarily follow that the underlying phenomena are not of a statistical nature. This only indicates that in this case they operate with averages, not with distributions of values (sampling).

We introduce the following classification of probabilistic mathematical models. We will distinguish partially probabilistic mathematical models of the thermal regime of a building in which the change of external climate parameters is regarded as a stochastic process, and all other factors and processes as 
deterministic and probabilistic mathematical models, in which, in addition to the external climate parameters, stochastic factors and other factors are considered stochastic . Thus, we determine the following classification of probabilistic and deterministic mathematical models of the thermal regime of a room:

1. Mathematical models of the thermal regime of the room as an object with distributed parameters (models that describe the temperature field in the plan and height of the room and separately take into account the radiant and convective heat exchange in the room).

2. Mathematical models of the thermal regime of the room as an object with partially distributed parameters (models that separately consider the radiant and convective heat exchange in the room, and the air temperature is assumed to be the same in the volume of the room).

3. Mathematical models of the thermal regime of the room as an object with concentrated parameters (models that describe the heat exchange in the room without dividing into convective and radiant components, and the air temperature is assumed to be the same in volume of the room).

The purpose of designing and building energy efficient buildings is to make more efficient use of energy resources consumed in the energy supply of the building, through the use of innovative solutions that can be implemented technically, economically sound and environmentally and socially acceptable and do not change the usual way of life. Priority in the choice of energy-saving technologies has technical solutions that simultaneously contribute to improving the indoor climate and environmental protection. According to researchers designing energy efficient building in accordance with the principles of systematic analysis includes three stages:

- construction of a mathematical model of heat and mass transfer processes in a building, ie description of them in the language of mathematics;

- choice of target function, ie determination of limiting conditions and formulation of optimization problem depending on the purpose of optimization 
(reduction of energy costs for heating, reduction of the installation power of equipment, reduction of energy costs for air conditioning in the annual cycle, etc.);

- solution of the set optimization problem.

According to the principles of system analysis, it is advisable to consider two independent energy subsystems when designing an energy efficient building:

- the external climate as a source of energy;

- building as a single energy system.

The design of an energy efficient building is to optimize the three energy interconnected subsystems and the building as a whole as a single energy system and includes:

- determining the optimal architectural, planning, thermal or energy parameters of individual elements of the building, taking into account the relationship between them;

- determination of the optimum architectural, planning, thermal or energy parameters of the building as a single energy system.

When designing buildings, architectural and engineering decisions are made to improve energy efficiency.

We note that architectural solutions include:

- choosing the location of the building, taking into account the climatic features, terrain and existing buildings in the area of construction;

- general architectural and planning concept of the building;

- choice of shape and orientation of the house;

- the choice of glazing (area and placement of apertures) and sun protection;

- choice of structure and materials of external facing;

- internal planning of the building;

- the choice of the scheme of lighting organization. 
Engineering solutions include:

- choice of sources of heat supply, including the possibility of use unconventional energy sources;

- choice of heating, ventilation, air conditioning;

- choice of design and materials of external enclosures;

- choice of automatic control system of engineering equipment.

Conclusions and perspectives for further researches. One of the most urgent tasks in determining the level of energy efficiency of buildings and structures is the analysis of their heat balance, taking into account all energy incomes and energy losses, since, as a rule, the largest amounts of energy in the cold season are spent on heating the premises used, and in the warm season to cool them. or air conditioning. It is by the results of the analysis of the thermal balance of the building that you can determine the necessary parameters of thermal insulation and set the optimal mode of ventilation of the premises. Therefore, further development and creation of new models of thermal balance of premises is an important and urgent task.

\section{References.}

1. Research Report: Development of an automated monitoring system and short-term forecasting of heat consumption for efficient management of energy consumption of the MES of Ukraine (final). Sumy State University. Under the management Dr. of Technical Sciences, Associate Professor M.I. Sotnyk

2. Tabunshchikov Yu. A., Brodach M.M. Mathematical modeling and optimization of thermal efficiency of buildings. M.: AVOK-PRESS, 2002. $194 \mathrm{p}$.

3. Fokin K.F. Construction heat engineering of the enclosing parts of buildings. Ed. 3rd, rework. and ext. M.: Stroizdat, 1973. 287 p. 


\title{
МЕТОДОЛОГІЧНІ АСПЕКТИ ПРОЕКТУВАННЯ ЕКОЛОГІЧНОЇ ЕНЕРГОЕФЕКТИВНОЇ БУДІВЛІ
}

\author{
Даніслян А.Е., Болгарова Н.М.
}

Анотація. Стаття присвячена методології екологічного проектування енергоефективних будівель. Розглянуто поняття життєвого ијиклу екологічного об'єкта та екологізаиії життєвого иуиклу. Представлена та описана схема життєвого циклу екооб'єкта.

Розкрито базові принципів побудови геометрично інтерпретованих фізико-математичних моделей прочесів теплообміну енергоефективних будинків. Відзначено, щзо застосування методів декомпозииї будівлі, доиільне для поділу об'єкта на простіші елементи, дозволяє представити будівлю у формі трьох основних енергетично взаємопов'язаних підсистем: енергетичним впливом зовнішнього клімату на оболонку будівлі; енергією, щุо міститься в оболонщі будівлі, тобто в зовнішніх огороджувальних конструкціях будівлі; енергією, щуо міститься всередині будівлі, тобто у внутрішньому повітрі, внутрішньому обладнанні, внутрішніх огороджувальних конструкиіях тощяо. При необхідності кожна із вказаних підсистем може бути представлена методом декомпозиції більш дрібними енергетично взаємопов'язаними елементами. Проектування енергоефективної будівлі полягає в оптимізаиіі трьох енергетично взаємопов'язаних підсистем і будівлі в цілому як єдиної енергетичної системи.

Також, в статті наведено три етапи, які включає в себе проектування енергоефективної будівлі відповідно до принщипів системного аналізу: побудова математичної моделі тепломасообмінних процесів в будівлі; вибір цุільової функиї; рімення поставленої оптимізаційної задачі.

Отже, так як одним із найбільш актуальних завдань при визначенні рівня енергоефективності будівель та споруд є аналіз їх 
теплового балансу з урахуванням усіх енергонадходжень і енерговтрат, тому подальший розвиток та створення нових моделей теплового балансу приміщень є важливою й нагальною задачею.

Ключові слова. Еко-дизайн; екологізація в дизайні; життєвий цүикл об'єкта; енергоефективність; тепловий баланс. 